\title{
Seasonal transition from NO $x$ - to hydrocarbon- limited conditions for ozone production over the eastern United States in September
}

\section{Citation}

Jacob, Daniel J., Larry W. Horowitz, J. William Munger, Brian G. Heikes, Russell R. Dickerson, Richard S. Artz, and William C. Keene. 1995. "Seasonal Transition from NO x - to HydrocarbonLimited Conditions for Ozone Production over the Eastern United States in September." Journal of Geophysical Research 100 (D5): 9315. doi:10.1029/94jd03125.

\section{Published Version}

doi:10.1029/94JD03125

\section{Permanent link}

http://nrs.harvard.edu/urn-3:HUL.InstRepos:14121760

\section{Terms of Use}

This article was downloaded from Harvard University's DASH repository, and is made available under the terms and conditions applicable to Other Posted Material, as set forth at http:// nrs.harvard.edu/urn-3:HUL.InstRepos:dash.current.terms-of-use\#LAA

\section{Share Your Story}

The Harvard community has made this article openly available.

Please share how this access benefits you. Submit a story.

Accessibility 


\title{
Seasonal transition from NOx- to hydrocarbon-limited conditions for ozone production over the eastern United States in September
}

\author{
Daniel J. Jacob, ${ }^{1}$ Larry W. Horowitz, ${ }^{1}$ J. William Munger, ${ }^{1}$ Brian G. Heikes, ${ }^{2}$ \\ Russell R. Dickerson, ${ }^{3}$ Richard S. Artz, ${ }^{4}$ and William C. Keene ${ }^{5}$
}

\begin{abstract}
Concentrations of $\mathrm{O}_{3}, \mathrm{CO}, \mathrm{NO}$, total reactive nitrogen oxides $\left(\mathrm{NO}_{\mathrm{y}}\right), \mathrm{H}_{2} \mathrm{O}_{2}$, and $\mathrm{HCHO}$ were measured from September 4 to October 1, 1990, at a mountain ridge site in Shenandoah National Park, Virginia. The data show evidence for a transition from $\mathrm{NO}_{\mathrm{x}}$-limited to hydrocarbon-limited conditions for $\mathrm{O}_{3}$ production over the course of September. The transition is diagnosed by large decreases of the $\mathrm{H}_{2} \mathrm{O}_{2} /\left(\mathrm{NO}_{\mathrm{y}}-\mathrm{NO}_{\mathrm{x}}\right)$ and $\mathrm{HCHO} / \mathrm{NO}_{y}$ concentration ratios, weakening of the correlation between $\mathrm{O}_{3}$ and $\mathrm{NO}_{\mathrm{y}}$ $\mathrm{NO}_{\mathrm{x}}$ concentrations, and decrease of the slope $\Delta \mathrm{O}_{3} / \Delta\left(\mathrm{NO}_{\mathrm{y}}-\mathrm{NO}_{\mathrm{x}}\right)$. A high- $\mathrm{O}_{3}$ episode occurring in late September was associated with only $0.34 \mathrm{ppbv}_{2} \mathrm{O}_{2}$, indicative of hydrocarbon-limited conditions. A seasonal transition in photochemical regime over the eastern United States in September would be expected from theory; the production rate of odd hydrogen radicals decreases by a factor of 2 over the course of the month, due to decreasing UV radiation and humidity, allowing $\mathrm{HNO}_{3}$ production to become the dominant sink for odd hydrogen in the boundary layer and resulting in hydrocarbonlimited conditions for $\mathrm{O}_{3}$ production. Seasonal decline of isoprene emission can greatly accentuate the transition.
\end{abstract}

\section{Introduction}

Ozone is produced in the troposphere by a chain reaction involving photochemical oxidation of hydrocarbons and $\mathrm{CO}$ in the presence of nitrogen oxides $\left(\mathrm{NO}_{\mathrm{x}}=\mathrm{NO}+\mathrm{NO}_{2}\right)$ [Chameides and Walker, 1973; Crutzen, 1973]. High $\mathrm{O}_{3}$ concentrations are frequently observed in surface air over the eastern United States, because of high emissions of $\mathrm{NO}_{\mathrm{x}}$ and hydrocarbons, and represent a serious air pollution problem [National Research Council (NRC), 1991]. It is well established, based on both observations and models, that $\mathrm{O}_{3}$ production over the eastern United States in summer is limited primarily by the supply of $\mathrm{NO}_{\mathrm{x}}$ [Trainer et al., 1987, 1993; Chameides et al., 1988, 1992; Sillman et al., 1990a; McKeen et al., 1991a; Jacob et al., 1993]. However, Kleinman [1991] has argued from theoretical considerations that a

${ }^{1}$ Division of Applied Sciences and Department of Earth \& Planetary Sciences, Harvard University, Cambridge, Massachusetts.

${ }^{2}$ Graduate School of Oceanography, University of Rhode Island, Narragansett, Rhode Island.

${ }^{3}$ Department of Meteorology, University of Maryland, College Park, Maryland.

${ }^{4}$ Air Resources Lab, NOAA, Silver Spring, Maryland.

${ }^{5}$ Department of Environmental Sciences, University of Virginia, Charlottesville, Virginia.

Copyright 1995 by the American Geophysical Union.

Paper number 94JD03125.

0148-0227/95/94JD-03125\$05.00 seasonal transition from $\mathrm{NO}_{\mathrm{x}}$ - to hydrocarbon-limited conditions should take place in the region between summer and winter. We report here evidence for such a transition using measurements made at Shenandoah National Park, Virginia, in September 1990 during the Shenandoah Cloud and Photochemistry Experiment (SCAPE). We present photochemical model calculations suggesting that a September transition is a general phenomenon in the eastern United States.

The argument of Kleinman [1991] is based on the titration of odd hydrogen by $\mathrm{NO}_{\mathrm{x}}$ in the continental boundary layer. Odd hydrogen $(\mathrm{odd} \mathrm{H})$ is the chemical family including $\mathrm{OH}$ and peroxy radicals $\left(\mathrm{RO}_{2}\right)$. Cycling of odd $\mathrm{H}$ propagates the chain reaction for $\mathrm{O}_{3}$ production. The principal source of odd $\mathrm{H}$ in the United States boundary layer is the photolysis of $\mathrm{O}_{3}$ to $\mathrm{O}\left({ }^{1} D\right)$ followed by reaction of $\mathrm{O}\left({ }^{1} D\right)$ with $\mathrm{H}_{2} \mathrm{O}$ [McKeen et al., 1991b]. Photolysis of aldehydes and peroxides provide additional sources. Whether $\mathrm{O}_{3}$ production is $\mathrm{NO}_{\mathrm{x}}$ - or hydrocarbon-limited is determined by the pathway for odd-H loss [Sillman et al., 1990a]. If loss is principally by self-reaction of peroxy radicals, producing peroxides, then $\mathrm{O}_{3}$ production tends to be $\mathrm{NO}_{x}$-limited. If loss is principally by reaction of $\mathrm{NO}_{2}$ with $\mathrm{OH}$ to produce $\mathrm{HNO}_{3}$, then $\mathrm{O}_{3}$ production tends to be hydrocarbon-limited. Kleinman [1991] points out that the odd-H production rate over the eastern United States decreases by 1 order of magnitude from summer to winter, due to declining UV radiation and humidity, crossing the point where odd- $\mathrm{H}$ radicals can be titrated in the boundary layer by $\mathrm{NO}_{x}$ emissions and resulting in a seasonal transition from $\mathrm{NO}_{\mathrm{x}}$ - to hydrocarbon-limited conditions. The transition is theoretically possible as soon as odd- $\mathrm{H}$ production drops to less than 2 times the $\mathrm{NO}_{\mathrm{x}}$ emission rate, but whether it actually takes place depends on the hydrocarbon/ $\mathrm{NO}_{\mathrm{x}}$ concentration ratio and on the mechanism for $\mathrm{NO}_{\mathrm{x}}$ oxidation [Sillman, 1995]. 
A seasonal transition in photochemical regime would be of little interest if it occurred in late fall when $\mathrm{O}_{3}$ production is slow. However, a September transition would have important implications for the design of air pollution control strategies because $\mathrm{O}_{3}$ concentrations during that month are still high. An analysis of data at rural sites in the eastern United States in September [Logan, 1988] indicates mean daily maximum $\mathrm{O}_{3}$ concentrations of 50-65 parts per billion by volume (ppbv), an average of 5 days per site per month with concentrations higher than $80 \mathrm{ppbv}$, and occasional violations of the federal air quality standard (120 ppbv). $\mathrm{A} \mathrm{NO}_{\mathrm{x}}$-only emission control strategy designed to reduce $\mathrm{O}_{3}$ levels in summer might be ineffective in September.

We diagnose the photochemical regime for $\mathrm{O}_{3}$ production in the SCAPE data set by using as indicators the concentration ratios $\mathrm{H}_{2} \mathrm{O}_{2} /\left(\mathrm{NO}_{\mathrm{y}}-\mathrm{NO}_{\mathrm{x}}\right)$ and $\mathrm{HCHO} / \mathrm{NO}_{\mathrm{y}}$ [Sillman, 1995], and the correlation between $\mathrm{O}_{3}$ and $\mathrm{NO}_{\mathrm{y}}-\mathrm{NO}_{\mathrm{x}}$ [Trainer et al., 1993]. Here $\mathrm{NO}_{\mathrm{y}}$ represents the sum of all reactive nitrogen oxide species, including $\mathrm{NO}_{\mathrm{x}}$ and its oxidation products $\left(\mathrm{HNO}_{3}\right.$, aerosol nitrate, organic nitrates). Thus $\mathrm{NO}_{y}-\mathrm{NO}_{\mathrm{x}}$ represents the sum of the products of $\mathrm{NO}_{\mathrm{x}}$ oxidation. Nitric acid accounts for about half of $\mathrm{NO}_{\mathrm{y}}-\mathrm{NO}_{\mathrm{x}}$ over the eastern United States in summer [Buhr et al., 1990; Parrish et al., 19931. The $\mathrm{H}_{2} \mathrm{O}_{2} /\left(\mathrm{NO}_{\mathrm{y}}-\mathrm{NO}_{\mathrm{x}}\right)$ ratio gives a measure of the relative rates of odd-H loss by the $\mathrm{NO}_{\mathrm{x}}$-limited versus hydrocarbon-limited pathways, while the $\mathrm{HCHO} / \mathrm{NO}_{\mathrm{y}}$ ratio gives a measure of the reactivity-weighted hydrocarbon/ $\mathrm{NO}_{\mathrm{x}}$ emission ratio. Based on photochemical model calculations for the U.S. boundary layer over a range of conditions, Sillman [1995] finds that the transition from hydrocarbon- to $\mathrm{NO}_{\mathrm{x}}$-limited conditions should take place at a consistent $\mathrm{H}_{2} \mathrm{O}_{2} /\left(\mathrm{NO}_{\mathrm{y}}-\mathrm{NO}_{\mathrm{x}}\right)$ ratio of 0.2 $\mathrm{mol} / \mathrm{mol}$ and at $\mathrm{HCHO} / \mathrm{NO}_{\mathrm{y}}$ ratios in the range $0.2-0.4 \mathrm{~mol} / \mathrm{mol}$.

The strong correlation observed between $\mathrm{O}_{3}$ and $\mathrm{NO}_{\mathrm{y}}-\mathrm{NO}_{x}$ at eastern U.S. sites in summer has been used previously as evidence of $\mathrm{NO}_{\mathrm{x}}$-limited conditions for $\mathrm{O}_{3}$ production [Trainer et al., 1993; Kleinman et al., 1994]. The slope $\Delta \mathrm{O}_{3} / \Delta\left(\mathrm{NO}_{\mathrm{y}}-\mathrm{NO}_{\mathrm{x}}\right)$ gives an estimate of the net $\mathrm{O}_{3}$ production efficiency, i.e., the net production of $\mathrm{O}_{3}$ per unit $\mathrm{NO}_{\mathrm{x}}$ consumed (this estimate is an upper limit because of $\mathrm{HNO}_{3}$ deposition [Chin et al., 1994]). As the atmosphere evolves from $\mathrm{NO}_{\mathrm{x}}$ - to hydrocarbon-limited, both the strength and the slope of the correlation would be expected to decrease [Lin et al., 1988; Sillman, 1995].

\section{Observations}

Air was sampled from a tower $3 \mathrm{~m}$ above the top of the forest canopy at the Pinnacles mountain ridge site (1037-m altitude) in Shenandoah National Park, Virginia $\left(39^{\circ} \mathrm{N}, 78^{\circ} \mathrm{W}\right)$. Concentra-

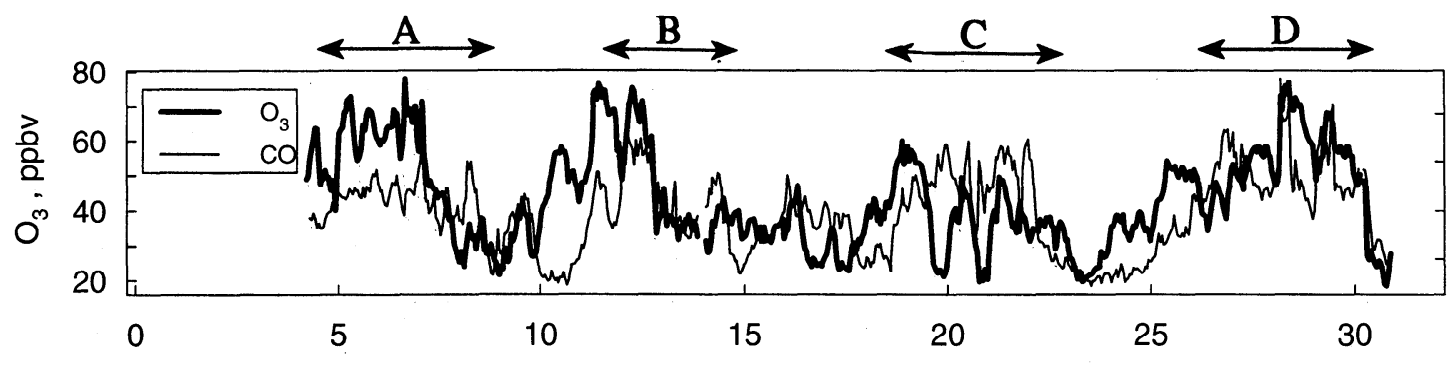

300
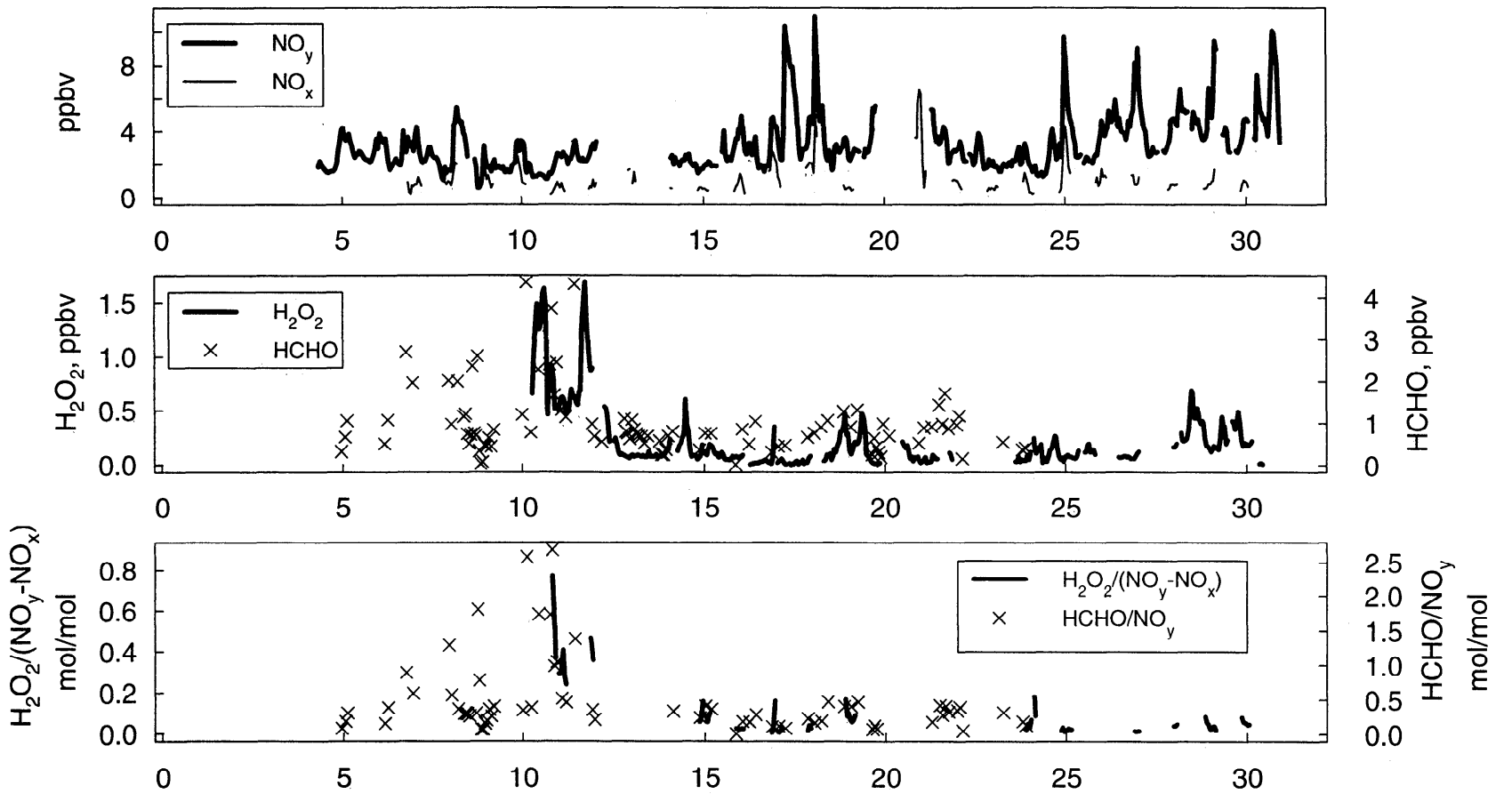

SEPTEMBER DAY

Figure 1. Time series of $\mathrm{O}_{3}, \mathrm{CO}, \mathrm{NO}_{\mathrm{y}}, \mathrm{NO}_{\mathrm{x}}, \mathrm{H}_{2} \mathrm{O}_{2}$, and $\mathrm{HCHO}$ concentrations and of the $\mathrm{H}_{2} \mathrm{O}_{2} /\left(\mathrm{NO}_{\mathrm{y}}-\mathrm{NO}_{\mathrm{x}}\right)$ and $\mathrm{HCHO} / \mathrm{NO}_{\mathrm{y}}$ concentration ratios at the Pinnacles site in Shenandoah National Park during September 1990. Tick marks on the abscissa indicate local noon for the given day. 
tions of $\mathrm{O}_{3}, \mathrm{CO}, \mathrm{NO}_{\mathrm{y}}$, and $\mathrm{NO}$ were measured from September 4 to October 1, 1990, using instrumentation described by Poulida et al. [1991] and Doddridge et al. [1992]. The inlet of the $\mathrm{NO}_{\mathrm{y}}$ instrument was equipped with a 5 to $10 \mu \mathrm{m}$ pore size Teflon filter, excluding coarse nitrate aerosol. Concentrations of $\mathrm{H}_{2} \mathrm{O}_{2}$ and organic peroxides were measured from September 10 to 30 using instrumentation described by Heikes [1992]. Concentrations of $\mathrm{HCHO}, \mathrm{CH}_{3} \mathrm{C}(\mathrm{O}) \mathrm{CHO}$, and $\mathrm{CHOCHO}$ were measured from September 5 to 24 [Munger et al., this issue]. Grab hydrocarbon samples were collected from September 4 to 14 (D. Pierotti, unpublished data, 1994). Additional measurements at the site included organic acids and cloudwater composition [Keene et al., this issue; Talbot et al., this issue]. Meteorological measurements included wind speed and direction, temperature, humidity, pressure, and UV radiation zenith and nadir (Eppley Laboratory, Incorporated). Three-day back trajectories for air arriving at the site at 12 GMT each day were calculated using three-dimensional winds from the National Weather Service Nested Grid Model [Draxler, 1992]. Two-thirds of the trajectories originated in the NW quadrant.

Figure 1 shows the time series of hourly mean $\mathrm{O}_{3}, \mathrm{CO}, \mathrm{NO}_{y}$, $\mathrm{H}_{2} \mathrm{O}_{2}$, and $\mathrm{HCHO}$ concentrations. Diel variations are small, as is typical of mountain sites [Aneja et al., 1991; Poulida et al., 1991]. There are four multiday pollution episodes defined by diel mean $\mathrm{CO}$ concentrations higher than $200 \mathrm{ppbv}$ and labeled in Figure 1 as A (September 5-8), B (September 12-14), C (September 19-22), and $\mathrm{D}$ (September 27-30). All four episodes developed in association with weak anticyclones, as is typical of regional-scale pollution events in the eastern United States [Logan, 1989]. Back trajectories for each episode (Figure 2) suggest that the air remained in the continental boundary layer for at least 3 days before reaching the site and passed over major urban and industrial regions during that period. The $\mathrm{O}_{3}$ maxima in episodes $\mathrm{A}, \mathrm{B}$, and $\mathrm{D}$

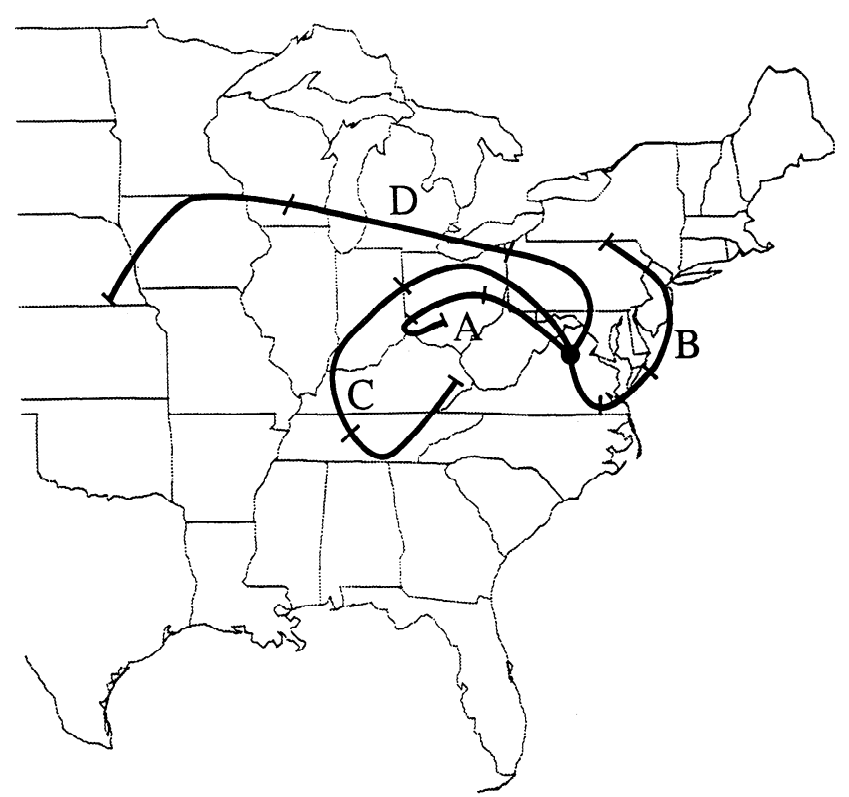

Figure 2. Three-day back trajectories for air arriving at the Pinnacles site at 12 GMT on September 6 (episode A), 13 (B), 20 (C), and 27 (D). The trajectories were generated using threedimensional winds from the National Weather Service Nested Grid Model [Draxler, 1992]. Tick marks along the trajectories separate 24-hour segments. All four trajectories remained in the boundary layer (below 900 mbar) for the 3 days before reaching the site. exceeded 75 ppbv; the maximum in episode $C$ was only 60 ppbv, likely because of cloudiness.

Ozone concentrations in the SCAPE data set were not correlated with $\mathrm{NO}_{\mathrm{y}}(r=-0.05)$. This result may be explained by the presence of large sources of $\mathrm{NO}_{x}$ from power plants a few hundred kilometers to the north and west of the site [Environmental Protection Agency (EPA), 1989; Moy et al., 1994]. Ozone concentrations in fresh $\mathrm{NO}_{x}$ plumes are low because $\mathrm{NO}_{\mathrm{x}}$ has not yet realized its $\mathrm{O}_{3}$ production potential [Chin et al., 1994]. Better correlation would be expected between $\mathrm{O}_{3}$ and $\mathrm{NO}_{\mathrm{y}}-\mathrm{NO}_{\mathrm{x}}$ [Trainer et al., 1993]. Concentrations of $\mathrm{NO}_{2}$ were not measured during SCAPE but are cstimated here for daytimc conditions (sun angle $<$ $70^{\circ}$ ) by assuming photochemical steady state between photolysis of $\mathrm{NO}_{2}$ to $\mathrm{NO}$ on the one hand and conversion of $\mathrm{NO}$ to $\mathrm{NO}_{2}$ by reaction with $\mathrm{O}_{3}$ and peroxy radicals on the other hand. Hourly data for the $\mathrm{NO}_{2}$ photolysis rate constant are derived from the Epplcy UV radiation data using the parameterization of Madronich [1987]. The concentrations of peroxy radicals are obtained from a steady state, zero-dimensional photochemical model constrained with hourly data for $\mathrm{NO}, \mathrm{O}_{3}, \mathrm{H}_{2} \mathrm{O}, \mathrm{CO}$, and temperature, and fixed concentrations of $1 \mathrm{ppbv} \mathrm{HCHO}, 1 \mathrm{ppbv}$ isoprene, and 1700 ppbv $\mathrm{CH}_{4}$. The model uses a chemical mechanism based on recent compilations of laboratory data [Atkinson, 1990; DeMore et al., 1992; Paulson and Seinfeld, 1992; Atkinson et al., 1993]. Photolysis rates for species other than $\mathrm{NO}_{2}$ are computed using a six-stream radiative transfer code for the Rayleigh scattering atmosphere with a UV surfacc albedo of 0.03 , an $\mathrm{O}_{3}$ column of $7.7 \times 10^{18}$ molecules $\mathrm{cm}^{-2} \mathrm{~s}^{-1}$, and an aerosol optical depth for absorption of 0.13 at $310 \mathrm{~nm}$ varying inversely with wavelength ¡Logan et al., 1981]. Cloud effects are accounted for by scaling the clear-sky photolysis rate constants computed with the code to the $\mathrm{NO}_{2}$ photolysis rate constant derived from the Eppley data.

The resulting time series of daytime $\mathrm{NO}_{\mathrm{x}}$ concentrations, including observed $\mathrm{NO}$ and modeled $\mathrm{NO}_{2}$, is shown in Figure 1. The mean $\mathrm{NO}_{2} / \mathrm{NO}$ ratio is $4.5 \mathrm{~mol} / \mathrm{mol}$ and the mean $\mathrm{NO}_{x} / \mathrm{NO}_{y}$ ratio is $0.31 \mathrm{~mol} / \mathrm{mol}$. The $\mathrm{NO}_{2}$ concentrations are relatively insensitive to the modeled peroxy radical concentrations because reaction with $\mathrm{O}_{3}$ accounts on average for $83 \%$ of the total NO sink in the model (i.e., the mean $\mathrm{NO}_{2} / \mathrm{NO}$ ratio would be $3.7 \mathrm{~mol} / \mathrm{mol}$ if reaction of $\mathrm{NO}$ with peroxy radicals were ignored).

A scalterplot of $\mathrm{O}_{3}$ versus $\mathrm{NO}_{y}-\mathrm{NO}_{x}$ concentrations is shown in Figure 3. There is no significant correlation for the SCAPE data set as a whole. There is however significant correlation in the September 4-12 data $\left(r^{2}=0.49, n=51\right)$ with a slope $\Delta \mathrm{O}_{3} / \Delta\left(\mathrm{NO}_{\mathrm{y}}-\mathrm{NO}_{\mathrm{x}}\right)=18 \mathrm{~mol} / \mathrm{mol}$ obtained from the reducedmajor-axis method. The relationship between $\mathrm{O}_{3}$ and $\mathrm{NO}_{y}-\mathrm{NO}_{x}$ in the September 4-12 data is consistent with previous observations at eastern U.S. sites in summer [Olszyna et al., 1993; Trainer et al., 1993; Kleinman et al., 1994]. The slopes reported in these previous studies are lower $(8-14 \mathrm{~mol} / \mathrm{mol})$, but the difference appears to reflect in part the choice of statistical approach.

The September 13-30 data show a weaker correlation between $\mathrm{O}_{3}$ and $\mathrm{NO}_{\mathrm{y}}-\mathrm{NO}_{\mathrm{x}}\left(r^{2}=0.23, n=107\right)$ and a lower slope $\left(\Delta \mathrm{O}_{3} / \Delta\left(\mathrm{NO}_{\mathrm{y}}-\mathrm{NO}_{\mathrm{x}}\right)=7 \mathrm{~mol} / \mathrm{mol}\right)$, suggesting that $\mathrm{O}_{3}$ production is less $\mathrm{NO}_{\mathrm{x}}$-limited than in early September. The weak correlation is due in part to occurrences of high $\mathrm{NO}_{\mathrm{y}}-\mathrm{NO}_{\mathrm{x}}$ (4-8 ppbv) associated with relatively low $\mathrm{O}_{3}$ (30-60 ppbv). The September 4-12 data show no such occurrences of high $\mathrm{NO}_{\mathrm{y}}-\mathrm{NO}_{\mathrm{x}}$ that could be used for comparison. However, the summertime data of Trainer et al. [1993] show a strong linear relationship between $\mathrm{O}_{3}$ and $\mathrm{NO}_{y}-\mathrm{NO}_{x}$ extending up to at least $10 \mathrm{ppbv} \mathrm{NO}_{\mathrm{y}}-\mathrm{NO}_{\mathrm{x}}$, with $6 \mathrm{ppbv}$ $\mathrm{NO}_{y}-\mathrm{NO}_{x}$ associated on average with 80-100 ppbv $\mathrm{O}_{3}$. The cause for the high $\mathrm{NO}_{\mathrm{y}}-\mathrm{NO}_{\mathrm{x}}$ values in the late-September SCAPE data is 


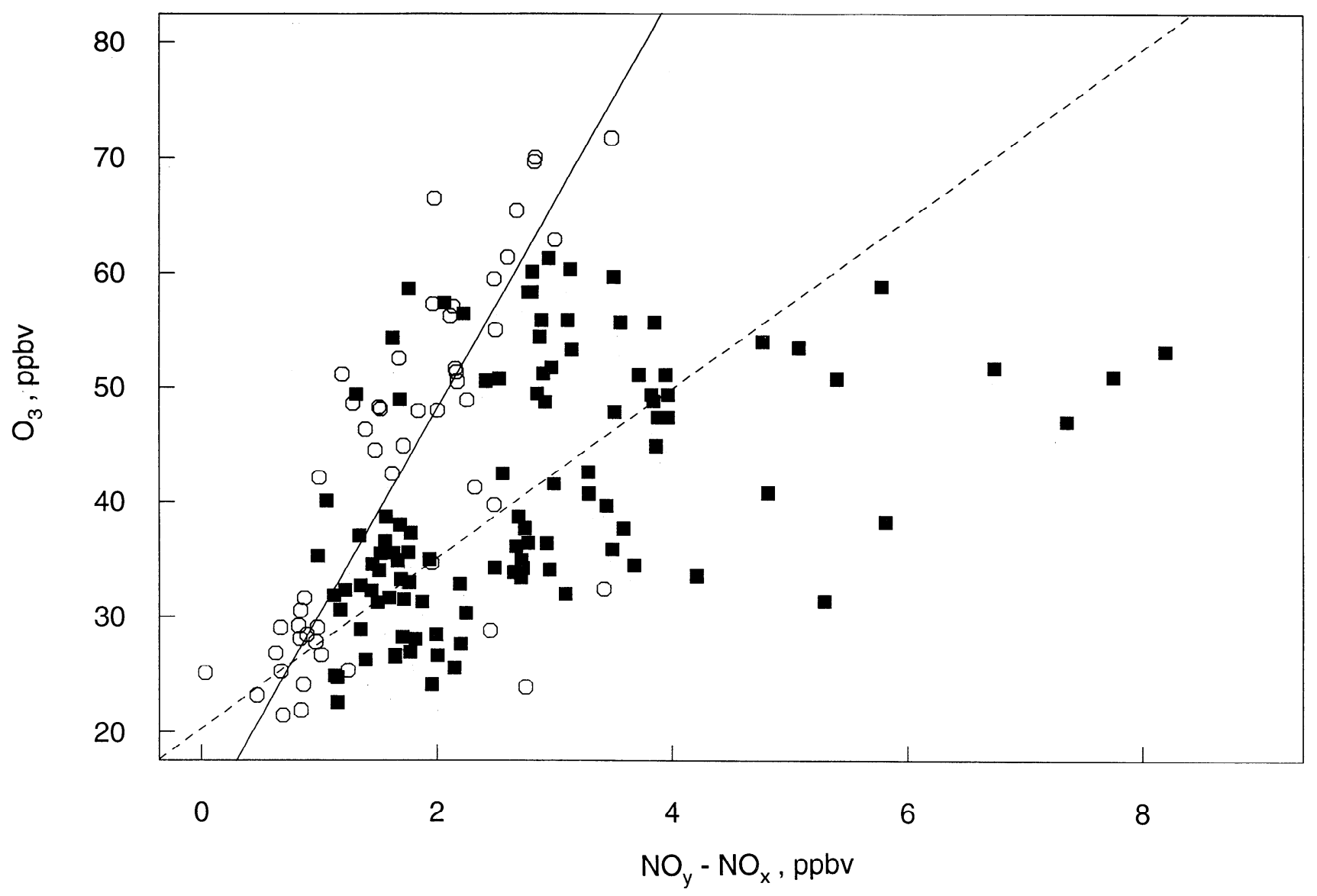

Figure 3. Scatterplot of hourly mean $\mathrm{O}_{3}$ versus $\mathrm{NO}_{y}-\mathrm{NO}_{x}$ concentrations and linear best fits (reduced-major-axis method) for September 4-12 (circles, solid line) and September 13-30 (squares, dashed line). Correlation coefficients and slopes are given in Table 1.

unclear. Inspection of back trajectories shows no obvious correlation with air mass origin.

The time series of $\mathrm{H}_{2} \mathrm{O}_{2}$ concentrations in Figure 1 offers additional evidence for a transition in photochemical regime during SCAPE. Concentrations decreased abruptly on September 12, in association with a cold front, and remained low thereafter, averaging $0.13 \mathrm{ppbv}$ for September 13-30 as compared to 0.86 ppbv for September 10-12. The $\mathrm{H}_{2} \mathrm{O}_{2} /\left(\mathrm{NO}_{\mathrm{y}}-\mathrm{NO}_{\mathrm{x}}\right)$ concentration ratio avcraged $0.40 \mathrm{~mol} / \mathrm{mol}$ on September $10-12$ and 0.049 $\mathrm{mol} / \mathrm{mol}$ on September 13-30; after September 12 it never rose above the value of $0.2 \mathrm{~mol} / \mathrm{mol}$ given by Sillman [1995] as the crossover point between $\mathrm{NO}_{\mathrm{x}}$ - and hydrocarbon-limited regimes for $\mathrm{O}_{3}$ production.

Although our $\mathrm{H}_{2} \mathrm{O}_{2}$ record is limited, measurements at other mountain sites in the southeastern United States show that the $\mathrm{H}_{2} \mathrm{O}_{2}$ concentrations measured on September 10-12 during SCAPE are typical of summer values in the region, while the concentrations measured after September 12 are typical of fall values. At Whitetop Mountain, Virginia, measurements were made during July-August and on October 4-14, 1986 [Olszyna et al., 1988]. The mean July-August concentration was 0.8 ppbv, with only $6 \%$ of observations less than $0.2 \mathrm{ppbv}$, while the mean October concentration was $0.15 \mathrm{ppbv}$ with no observations above $0.6 \mathrm{ppbv}$. At Mount Mitchell, North Carolina, measurements were made during July-August and on September 14-18, 1988 [Claiborn and Aneja, 1991]. The mean July-August concentration was $0.8 \mathrm{ppbv}$, with less than $10 \%$ of values less than $0.25 \mathrm{ppbv}$, while a drop from 1.0 ppbv to 0.1 ppbv was observed during the September 14-18 period. These three data sets taken together suggest a factor of 5 or more seasonal decrease of $\mathrm{H}_{2} \mathrm{O}_{2}$ concentrations during the month of September. Such a decrease is predicted by Kleinman [1991], who attributes it to the suppression of $\mathrm{H}_{2} \mathrm{O}_{2}$ formation following titration of odd- $\mathrm{H}$ by $\mathrm{NO}_{\mathrm{x}}$ emissions. Aqueous-phase titration of $\mathrm{H}_{2} \mathrm{O}_{2}$ by $\mathrm{SO}_{2}$ [Daum et al., 1984] would also contribute to the decrease, but should have a less systematic effect because it operates only in cloud. There is a strong correlation between $\mathrm{H}_{2} \mathrm{O}_{2}$ and organic peroxides in the SCAPE data set $\left(r^{2}=0.68\right)$, suggesting that the decrease of $\mathrm{H}_{2} \mathrm{O}_{2}$ during September is photochemically controlled. Organic peroxides are not rapidly consumed by oxidation of $\mathrm{SO}_{2}$ in cloud because of their low solubility [Jacob et al., 1989a]

The $\mathrm{HCHO} / \mathrm{NO}_{\mathrm{y}}$ concentration ratio provides another indication of the transition in photochemical regime. Mean values observed in SCAPE are $0.67 \mathrm{~mol} / \mathrm{mol}$ for September $5-12$ and $0.25 \mathrm{~mol} / \mathrm{mol}$ for September 13-25 (Figure 1). The ratio varied considcrably before September 12, far less afterward; the maximum value observed after September 13 was $0.47 \mathrm{~mol} / \mathrm{mol}$. Sillman [1995] gives a crossover ratio of $0.2-0.4 \mathrm{~mol} / \mathrm{mol}$ for the transition from $\mathrm{NO}_{\mathrm{x}}$ - to hydrocarbon-limited conditions. The decrease of $\mathrm{HCHO} / \mathrm{NO}_{\mathrm{y}}$ could reflect the seasonal decline of biogenic isoprene emissions in September due to senescence of vegetation [Goldstein, 1994; Jobson et al., 1994; Monson et al., 1995].

Periods of high $\mathrm{O}_{3}$ (70-80 ppbv) during episodes $\mathrm{B}$ and $\mathrm{D}$ give an additional perspective on the transition. Mean concentrations 
Table 1. Photochemical Indicators at Shenandoah National Park

\begin{tabular}{lccr}
\hline Indicator & September 4-12 & September 13-30 & Crossover \\
\hline & & & \\
$\mathrm{H}_{2} \mathrm{O}_{2} /\left(\mathrm{NO}_{\mathrm{y}}-\mathrm{NO}_{\mathrm{x}}\right), \mathrm{mol} / \mathrm{mol}$ & $0.40(0.24-0.77)$ & $0.049(0.01-0.18)$ & 0.2 \\
$\mathrm{HCHO} / \mathrm{NO}_{\mathrm{y}}, \mathrm{mol} / \mathrm{mol}$ & $0.67(0.07-2.7)$ & $0.25(0.01-0.47)$ & $0.2-0.4$ \\
$\mathrm{O}_{3}$ versus $\mathrm{NO}_{\mathrm{y}}-\mathrm{NO}_{\mathrm{x}}:$ & & & \\
$r^{2}$ & 0.49 & 0.23 & \\
$\Delta \mathrm{O}_{3} / \Delta\left(\mathrm{NO}_{\mathrm{y}}-\mathrm{NO}_{\mathrm{x}}\right), \mathrm{mol} / \mathrm{mol}$ & 18 & 7 & \\
\hline
\end{tabular}

Means and ranges of observed $\mathrm{H}_{2} \mathrm{O}_{2} /\left(\mathrm{NO}_{\mathrm{y}}-\mathrm{NO}_{\mathrm{x}}\right)$ and $\mathrm{HCHO} / \mathrm{NO}_{\mathrm{y}}$ concentration ratios; the crossover values represent the transition from $\mathrm{NO}_{\mathrm{x}}$ - to hydrocarbon-limited conditions for $\mathrm{O}_{3}$ production according to the photochemical model calculations of Sillman [1995] (ratios lower than the crossover valuc correspond to the hydrocarbon-limited regime). The slope $\Delta \mathrm{O}_{3} / \Delta\left(\mathrm{NO}_{\mathrm{y}}-\mathrm{NO}_{\mathrm{x}}\right)$ of the $\mathrm{O}_{3}$ versus $\mathrm{NO}_{y}-\mathrm{NO}_{x}$ correlation was computed with the reduced-majoraxis method.

in episode B were 73 ppbv $\mathrm{O}_{3}, 2.6$ ppbv $\mathrm{NO}_{\mathrm{y}}, 0.63$ ppbv $\mathrm{H}_{2} \mathrm{O}_{2}$, and 2.5 ppbv HCHO (14 hours of data); in episode D they were 73 ppbv $\mathrm{O}_{3}, 5.2$ ppbv $\mathrm{NO}_{\mathrm{y}}$, and $0.34 \mathrm{ppbv} \mathrm{H}_{2} \mathrm{O}_{2}$ (9 hours of data; $\mathrm{HCHO}$ was not measured). The high- $\mathrm{O}_{3}$ periods occurred in the evening and night hours, when $\mathrm{NO}_{\mathrm{x}}$ could not be estimated. Nevertheless, the $\mathrm{NO}_{\mathrm{y}}$ and $\mathrm{H}_{2} \mathrm{O}_{2}$ data suggest that episode $\mathrm{D}$ was less $\mathrm{NO}_{x}$-limited than episode $\mathrm{B}$ for a similar amount of $\mathrm{O}_{3}$ pro- duced. $\mathrm{A} \mathrm{H}_{2} \mathrm{O}_{2}$ concentration of 0.34 ppbv for the continental boundary layer is clearly indicative of hydrocarbon-limited conditions in photochemical models [Dommen et al., 1995].

A summary of the chemical indicator data is given in Table 1. Each of the indicators, when considered individually, would be open to interpretations other than a seasonal transition in photochemical regime. Combination of the indicators makes a stronger

Table 2. Odd Hydrogen Production Rates at Shenandoah National Park

\begin{tabular}{|c|c|c|}
\hline & September 1 & October 1 \\
\hline Solar declination, degrees & +7.4 & -3.9 \\
\hline Temperature, $\mathrm{K}$ & 293 & 288 \\
\hline $\mathrm{H}_{2} \mathrm{O}, \mathrm{mol} / \mathrm{mol}$ & 0.017 & 0.013 \\
\hline $\mathrm{O}_{3}, \mathrm{ppbv}$ & 55 & 55 \\
\hline $\mathrm{HCHO}$, ppbv & 1.4 & 0.7 \\
\hline $\mathrm{H}_{2} \mathrm{O}_{2}, \mathrm{ppbv}$ & 0.8 & 0.2 \\
\hline $\mathrm{CH}_{3} \mathrm{C}(\mathrm{O}) \mathrm{CHO}, \mathrm{ppbv}$ & 0.017 & 0.020 \\
\hline Odd-H production rate, $10^{5}$ molecules $\mathrm{cm}^{-3} \mathrm{~s}^{-1}$ & & \\
\hline $\mathrm{O}\left({ }^{1} D\right)+\mathrm{H}_{2} \mathrm{O} \rightarrow 2 \mathrm{OH}$ & 12.7 & 6.0 \\
\hline $\mathrm{HCHO}+\mathrm{hv} \stackrel{2 \mathrm{O}_{2}}{\longrightarrow}>\mathrm{CO}+2 \mathrm{HO}_{2}$ & 3.6 & 1.4 \\
\hline $\mathrm{CH}_{3} \mathrm{C}(\mathrm{O}) \mathrm{CHO}+\mathrm{hv} \stackrel{2 \mathrm{O}_{2}}{\longrightarrow}>\mathrm{CO}+\mathrm{HO}_{2}+\mathrm{CH}_{3} \mathrm{CO}_{3}$ & 0.9 & 0.8 \\
\hline $\mathrm{H}_{2} \mathrm{O}_{2}+\mathrm{hv} \rightarrow>2 \mathrm{OH}$ & 0.4 & $<0.1$ \\
\hline Total & 18 & 8 \\
\hline
\end{tabular}

Odd $\mathrm{H}$ is the chemical family including $\mathrm{OH}$ and peroxy radicals. Temperatures, humidities, and concentrations of odd- $\mathrm{H}$ precursors are typical observations from SCAPE. The mean $\mathrm{CH}_{3} \mathrm{C}(\mathrm{O}) \mathrm{CHO}$ concentration measured in SCAPE was below the detection limit of 0.05 ppbv; the values used here are from the one-dimensional photochemical model of Munger et al. [this issue], assuming an isoprene emission flux of $5 \times 10^{10}$ molecules $\mathrm{cm}^{-2} \mathrm{~s}^{-1}$ (24-hour average). The odd-H production rates are 24-hour averages at $1 \mathrm{~km}$ altitude computed using a six-stream radiative transfer code for the Rayleigh scattering atmosphere [Logan et al., 1981] with photochemical data from DeMore et al. [1992]. We assume a UV surface albedo of 0.03 , an $\mathrm{O}_{3}$ column of $7.7 \times 10^{18}$ molecules $\mathrm{cm}^{-2}$ [Hilsenrath et al., 1979], an aerosol optical depth for absorption of 0.13 at $310 \mathrm{~nm}$ increasing inversely with wavelength, and $25 \%$ opaque cloud cover. 
case. However, it should be recognized that the indicators are not truly independent since they are all based on $\mathrm{NO}_{\mathrm{y}}$; in particular, the trends in the indicators over the course of September reflect partly a rise in $\mathrm{NO}_{\mathrm{y}}-\mathrm{NO}_{\mathrm{x}}$ for which we have no clear explanation. We present in what follows an independent model assessment of the seasonal transition in photochemical regime over the eastern United States.

\section{Model Calculations}

\section{Odd-H Production and $\mathrm{NO}_{\mathrm{x}}$ Emission}

A simple diagnosis of the photochemical regime for $\mathrm{O}_{3}$ production over the eastern United States can be made following Kleinman [1991] by comparing the rates of odd-H production and $\mathrm{NO}_{\mathrm{x}}$ emission in the region. Table 2 gives estimates of odd-H production rates at Shenandoah from photolysis of $\mathrm{O}_{3}, \mathrm{HCHO}$, $\mathrm{CH}_{3} \mathrm{C}(\mathrm{O}) \mathrm{CHO}$, and $\mathrm{H}_{2} \mathrm{O}_{2}$ under conditions representative of September $\mathrm{l}$ and October 1 . These four photolysis reactions account for over $90 \%$ of the total odd- $\mathrm{H}$ source in the boundary layer according to our photochemical model calculations (see below). The odd-H production rates in Table 2 are $1.8 \times 10^{6}$ molecules $\mathrm{cm}^{-3} \mathrm{~s}^{-1}$ on September 1 and $8 \times 10^{5}$ molecules $\mathrm{cm}^{-3} \mathrm{~s}^{-1}$ on October 1. The factor of 2 decrease over the course of September is driven largely by a $40 \%$ decline of radiation intensitics in the bandwidth for photolysis of $\mathrm{O}_{3}$ to $\mathrm{O}\left({ }^{1} \mathrm{D}\right)(300-320 \mathrm{~nm})$ and a $25 \%$ decline of $\mathrm{H}_{2} \mathrm{O}$ concentrations.

The mean emission of $\mathrm{NO}_{\mathrm{x}}$ in the eastern United States in summer is $1.9 \times 10^{11}$ molecules $\mathrm{cm}^{-2} \mathrm{~s}^{-1}$ (1985 inventory, cited by McKeen et al. [1991b]). Seasonal variation in this emission is small [EPA, 1989]. Assuming a 1.6-km-deep continental boundary layer in September [Holzworth, 1967], we derive a $\mathrm{NO}_{x}$ source in the boundary layer of $1.2 \times 10^{6}$ molecules $\mathrm{cm}^{-3} \mathrm{~s}^{-1}$. This source falls between our estimates of odd-H production on September 1 and October 1. Transition to a hydrocarbon-limited regime for $\mathrm{O}_{3}$ production during September could therefore be expected.

Several complications to this argument must be considered,

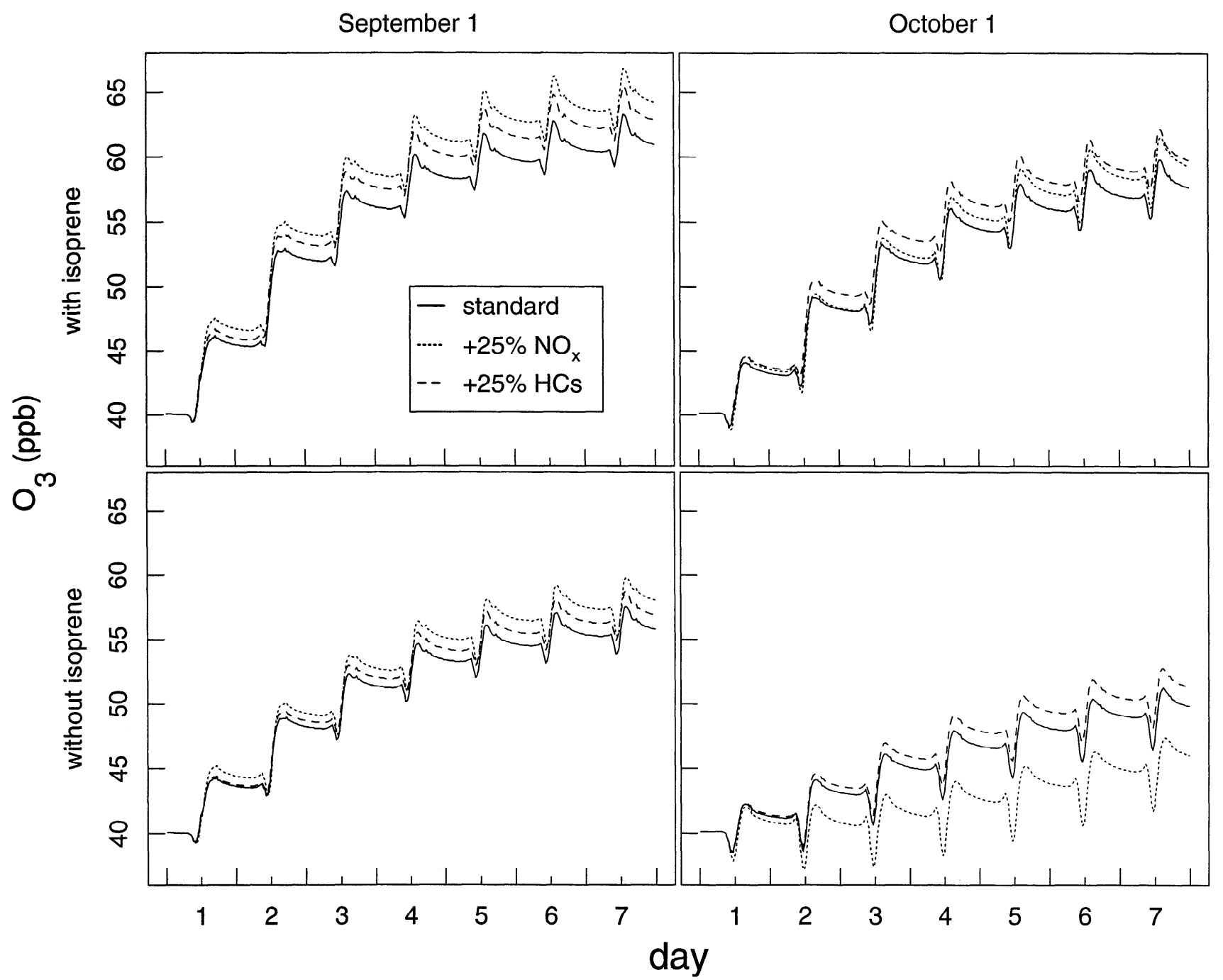

Figure 4. Ozone concentrations at 1-km altitude calculated with a one-dimensional photochcmical model for conditions representative of the eastern United States on September 1 and October 1 (left and right panels, respectivcly), with and without isoprene emission (top and bottom panels, respectively). The sharp rise of $\mathrm{O}_{3}$ concentrations at noon reflects the diurnal rise of the mixed layer above $1-\mathrm{km}$ altitude. Results from the standard simulation described in the text are compared to results from simulations with $\mathrm{NO}_{\mathrm{x}}$ or hydrocarbon (HCs) emissions increased by $25 \%$ (the increase in hydrocarbon emissions is applied to all non-methane hydrocarbons including isoprene). 
however. For example, nighttime hydrolysis of $\mathrm{N}_{2} \mathrm{O}_{5}$ in aerosols may delay or prevent the transition by consuming $\mathrm{NO}_{\mathrm{x}}$ without consuming odd $\mathrm{H}$. Conversion of $\mathrm{NO}_{x}$ to peroxyacetylnitrate (PAN) consumes odd $\mathrm{H}$ but does not lead to a hydrocarbonlimited regime [Sillman, 1995]. Declining emission of isoprene in September would by contrast hasten the transition because oxidation of isoprene provides a significant source of odd $\mathrm{H}$ and also decreases the fraction of odd- $\mathrm{H}$ present as $\mathrm{OH}$ (and hence available for reaction with $\mathrm{NO}_{2}$ ). We address here these complications by using a one-dimensional photochemical model for the continental boundary layer.

\section{One-Dimensional Model}

Our model is similar in structure to that used by Trainer et al. [1991] to simulate a summertime high- $\mathrm{O}_{3}$ episode at Scotia, Pennsylvania. It resolves the boundary layer with six grid points in the vertical extending to $1.8 \mathrm{~km}$. Vertical transport is represented by diurnally varying eddy diffusion coefficients. The mixed layer depth varies with time of day and peaks at $1.6 \mathrm{~km}$ during the afternoon hours. Ventilation of the boundary layer by the free troposphere takes place on a timescale of 4 days. The gas phase photochemical mechanism and the radiation code are as described in section 2. Hydrolysis of $\mathrm{N}_{2} \mathrm{O}_{5}$ in aerosols is included with a rate constant of $1 \times 10^{-4} \mathrm{~s}^{-1}$ [Dentener and Crutzen, 1993], so that loss of $\mathrm{NO}_{\mathrm{x}}$ at night is limited largely by the rate of the $\mathrm{NO}_{2}+\mathrm{O}_{3}$ reaction in the gas phase. Deposition velocities of $\mathrm{O}_{3}$. $\mathrm{NO}_{2}$. PAN, carbonyls. and peroxides at $10-\mathrm{m}$ altitude are $0.5 \mathrm{~cm}$ $\mathrm{s}^{-1}$ in the day and $0.1 \mathrm{~cm} \mathrm{~s}^{-1}$ at night. The deposition of $\mathrm{HNO}_{3}$ is limited by the rate of turbulent diffusion to the surface and is sufficiently fast that conversion to $\mathrm{HNO}_{3}$ is a terminal sink for $\mathrm{NO}_{\mathrm{x}}$.

We use the model to determine the sensitivity of $\mathrm{O}_{3}$ to $\mathrm{NO}_{x}$ and hydrocarbon emissions for conditions representative of September 1 and October 1 . The simulations are conducted for 7 days, starting from low initial concentrations (including $40 \mathrm{ppbv}$ $\mathrm{O}_{3}$ ) which are also taken as upper boundary conditions at $1.6 \mathrm{~km}$. Fixed concentrations are assumed for $\mathrm{CO}$ (200 ppbv), $\mathrm{CH}_{4}(1700$ ppbv), $\mathrm{C}_{2} \mathrm{H}_{6}(2.2 \mathrm{ppbv})$, and acetone (1 ppbv). Munger et al. [this issue] estimated an isoprene emission flux of $5 \times 10^{10}$ molecules $\mathrm{cm}^{-2} \mathrm{~s}^{-1}$ (24-hour average) from the SCAPE carbonyl data; as pointed out above, the HCHO data suggest a strong decline of isoprene over the course of September. We present here calculations both with and without isoprene emission. The diel variation of isoprene emission is specified following Jacob et al. [1989b].

We first applied the model to an atmosphere representative of average conditions in the eastern United States. Mean anthropogenic emissions of $\mathrm{NO}_{\mathrm{x}}$ and reactive non-methane hydrocarbons

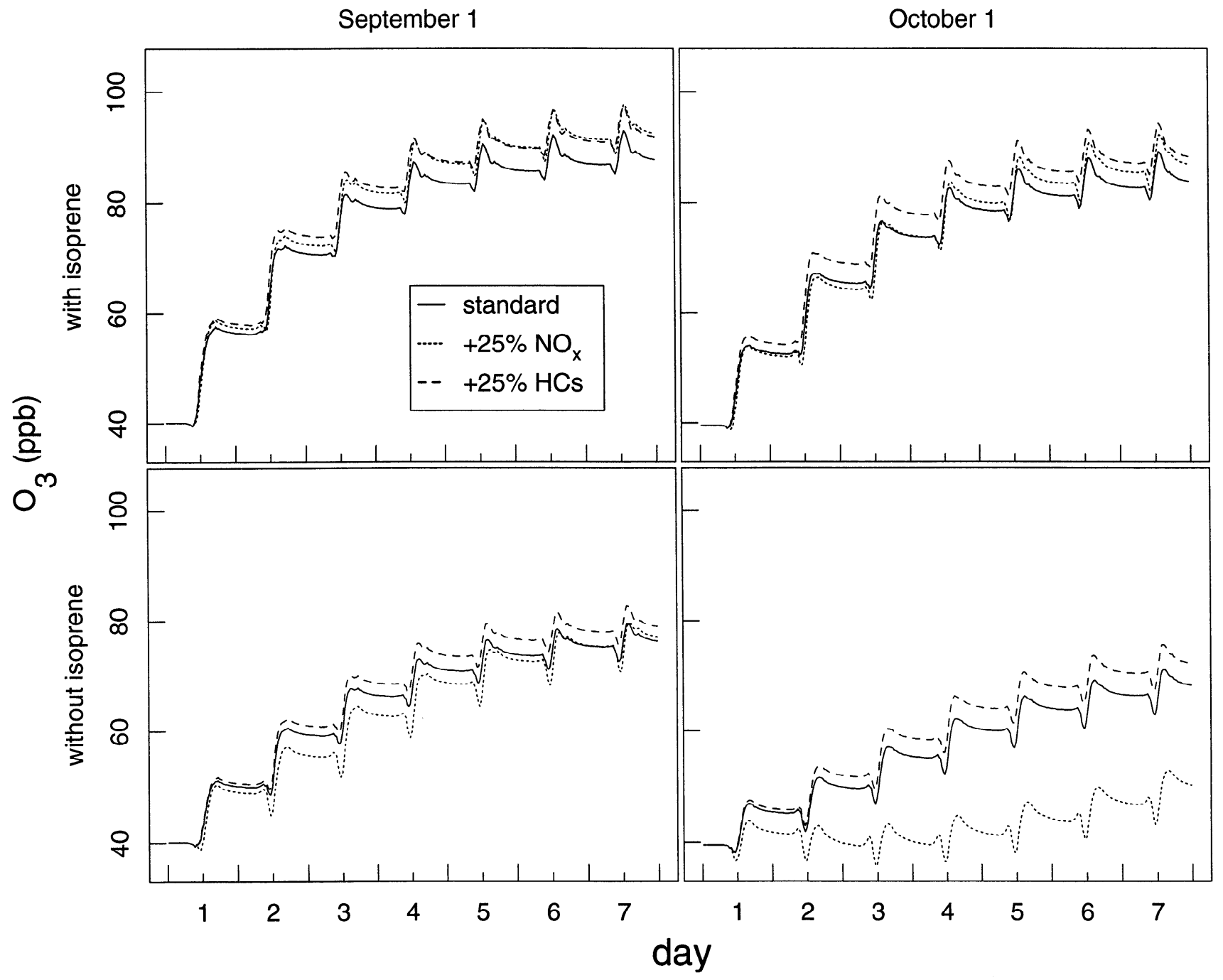

Figure 5. Same as Figure 4 but for a high- $\mathrm{O}_{3}$ episode (see text). 
for the region were taken from Table 6 of McKeen et al. [1991b]. On a reactivity-weighted basis [Trainer et al., 1991], the anthropogenic source of non-methane hydrocarbons is comparable to the biogenic source of isoprene. Meteorological and radiative conditions for September 1 and October 1 were as given in Table 2. The sensitivity of $\mathrm{O}_{3}$ to changes in $\mathrm{NO}_{\mathrm{x}}$ and hydrocarbon emissions was diagnosed by conducting simulations with $25 \%$ increases in emissions (the increase in hydrocarbon emissions was applied to all non-methane hydrocarbons including isoprene).

Figure 4 shows the simulated $\mathrm{O}_{3}$ concentrations at 1-km altitude. We find a positive dependence of $\mathrm{O}_{3}$ on $\mathrm{NO}_{\mathrm{x}}$ and hydrocarbon emissions in the September 1 cases, and in the October 1 case with isoprene; $\mathrm{NO}_{\mathrm{x}}$ is more limiting in the September 1 cases while hydrocarbons are more limiting in the October 1 case. The October 1 case without isoprene shows a negative dependence of $\mathrm{O}_{3}$ on $\mathrm{NO}_{\mathrm{x}}$ emissions, indicating strongly hydrocarbon-limited conditions.

We also applied the model to the simulation of a representative high- $\mathrm{O}_{3}$ episode. Anthropogenic emissions were doubled from the mean values for the eastern United States given by McKeen et al. [1991b]. We assumed clear skies, high temperature and humidity (September 1 values in Table 2); the only difference between the September 1 and October 1 simulations was the solar declination. Results are shown in Figure 5. Ozone concentrations in the October 1 cases reach 80 ppbv after 4 days with isoprene present and 60 ppbv without isoprene present. Hydrocarbon limitation of $\mathrm{O}_{3}$ production is more severe than in the previous simulation. The October 1 case without isoprene shows a precipitous $\mathrm{O}_{3}$ decrease when $\mathrm{NO}_{\mathrm{x}}$ emissions are increased by $25 \%$, reflecting an abrupt transition in photochemical regime of the type described by Kleinman [1991].

\section{Conclusions}

Measurements of $\mathrm{O}_{3}, \mathrm{CO}, \mathrm{NO}, \mathrm{NO}_{y}, \mathrm{H}_{2} \mathrm{O}_{2}$, and $\mathrm{HCHO}$ concentrations at Shenandoah National Park indicate a seasonal transition from $\mathrm{NO}_{\mathrm{x}}$ - to hydrocarbon-limited conditions for $\mathrm{O}_{3}$ production during September. The transition is diagnosed by large decreases of the $\mathrm{H}_{2} \mathrm{O}_{2} /\left(\mathrm{NO}_{\mathrm{y}}-\mathrm{NO}_{\mathrm{x}}\right)$ and $\mathrm{HCHO} / \mathrm{NO}_{\mathrm{y}}$ concentration ratios, degradation of the $\mathrm{O}_{3}$ versus $\mathrm{NO}_{\mathrm{y}}-\mathrm{NO}_{\mathrm{x}}$ correlation, and decrease of the slope $\Delta \mathrm{O}_{3} / \Delta\left(\mathrm{NO}_{\mathrm{y}}-\mathrm{NO}_{\mathrm{x}}\right)$. The $\mathrm{NO}_{\mathrm{x}}$ emissions in the area around Shenandoah National Park include an unusually high contribution from power plants [EPA, 1989], so that $\mathrm{O}_{3}$ production in the region might have a particularly high tendency to be hydrocarbon-limited [Sillman et al., 1990b]. However, our model calculations suggest that the seasonal transition in photochemical regime during September should be a general phenomenon in the eastern United States. The transition is driven by seasonal declines of UV radiation, humidity, and isoprene emission, allowing $\mathrm{HNO}_{3}$ production to become the dominant sink for odd $\mathrm{H}$ in the boundary layer. We would expect the reverse transition to take place in April.

A hydrocarbon-limited regime for $\mathrm{O}_{3}$ production over the eastern United States from September to April would have important implications for the design of $\mathrm{O}_{3}$ pollution control strategies. A strategy relying solely on $\mathrm{NO}_{\mathrm{x}}$ emission controls might be successful in summer but inadequate in spring or fall. We caution that the work presented here is preliminary; the data are sparse and the model calculations largely illustrative. Additional time series of observations are requircd to confirm and generalize the results observed in Shenandoah. Thorough documentation of high- $\mathrm{O}_{3}$ episodes occurring in spring and fall would be particularly valu- ablc. Simulations using a regional three-dimensional model are needed to better quantify the seasonal variations in photochemical regime across the range of conditions found in the eastern United States.

$>$ From a global perspective the main effect of hydrocarbonlimited photochemistry in polluted boundary layers would be to amplify the effect of changes in anthropogenic $\mathrm{NO}_{\mathrm{x}}$ emissions on the export of $\mathrm{NO}_{\mathrm{x}}$ out of the boundary layer and hence on tropospheric $\mathrm{O}_{3}$ and $\mathrm{OH}$. In the remote troposphere the supply of $\mathrm{NO}_{\mathbf{x}}$ is, in general, sufficiently low that $\mathrm{NO}_{\mathrm{x}}$-limited conditions should persist year-round. One possible exception is the upper troposphere, where odd-H production is slow (because of low humidity) and where $\mathrm{NO}_{\mathrm{x}}$ concentrations may be high as a result of lightning, aircraft, and convective updrafts.

Acknowledgments. This work was supported by National Science Foundation grants to Harvard University (ATM-8812157, ATM-9304217), the Universities of Rhode Island and Maryland (ATM-9015769), and the University of Virginia (ATM-8911815) and by a Packard Foundation grant to Harvard. The $\mathrm{H}_{2} \mathrm{O}_{2}$ measurements were supported by the Electric Power Research Institute under contract RP-2023-12. We thank K. Civerolo and B.G. Doddridge (U. of Maryland) and M. Lee (U. of Rhode Island) for their help in the field, and R. Shetter (NCAR) and R. Arnst (EPA) for the loan of equipment. We are indebted to the Mountain Cloud Chemistry Program and particularly John Sigmon, Patricia Thompson, David Krovitz, and Michael Reiter for the use of their facilities. The Shenandoah National Park Service provided on-site housing and laboratory space.

\section{References}

Aneja, V.P., S. Businger, Z. Li, C.S. Claiborn, and A. Murthy, Ozone climatology at high elevations in the southern Appalachians, J. Geophys. Res., 96, 1007-1021, 1991.

Atkinson, R., Gas-phase tropospheric chemistry of organic compounds: a review, Atmos. Environ., 24(A), 1-42, 1990.

Atkinson, R., D.L. Baulch, R.A. Cox, R.F. Hampson Jr., J.A. Kerr, and J. Troe, Evaluated kinetic and photochemical data for atmospheric chemistry, supplement IV, IUPAC subcommittee on gas kinetic data evaluation for atmospheric chemistry, $J$. Phys. Chem. Ref. Data, 21, 1125-1568, 1993.

Buhr, M. P., D. D. Parrish, R. B. Norton, F. C. Fehsenfeld, R. E. Sievers, and J. M. Roberts, Contribution of organic nitrates to the total reactive nitrogen budget at a rural eastern U.S. site, $J$. Geophys. Res., 95, 9809-9816, 1990.

Chameides, W.L., and J.C.G. Walker, A photochemical theory of tropospheric ozone, J. Geophys. Res., 78, 8751-8760, 1973.

Chameides, W.L., R.W. Lindsay, J. Richardson, and C.S. Kiang, The role of biogenic hydrocarbons in urban photochemical smog: Atlanta as a case study, Science, 241, 1473-1475, 1988.

Chameides, W.L., et al., Ozone precursor relationships in the ambient atmosphere, J. Geophys. Res., 97, 6037-6055, 1992.

Chin, M., D.J. Jacob, J.W. Munger, D.D. Parrish, and B.G. Doddridge, Relationship of ozone and carbon monoxide over North America, J. Geophys. Res., 99, 14,565-14,573, 1994.

Claiborn, C.S., and V.P. Aneja, Measurements of atmospheric hydrogen peroxide in the gas phase and in cloud water at Mt. Mitchell, North Carolina, J. Geophys. Res., 96, 18,771-18,787, 1991.

Crutzen, P. J., A discussion of the chemistry of some minor con- 
stituents in the stratosphere and troposphere, Pure Appl. Geophys., 106, 1385-1399, 1973.

Daum., P.H., S.E. Schwartz, and L. Newman, Acidic and related constituents in liquid-water clouds, J. Geophys. Res., 89, 1447-1458, 1984.

DeMore, W.B., S.P. Sander, D.M. Golden, M.J. Molina, R.F. Hampson, M.J. Kurylo, C.J. Howard, and A.R. Ravishankara, Chemical kinetics and photochemical data for use in stratospheric modeling, JPL Publ. 92-1, Pasadena, Calif., 1992.

Dentener, F.J., and P.J. Crutzen, Reaction of $\mathrm{N}_{2} \mathrm{O}_{5}$ on tropospheric aerosols: impact on the global distributions of $\mathrm{NO}_{\mathrm{x}}, \mathrm{O}_{3}$, and OH, J. Geophys. Res., 98, 7149-7163, 1993.

Doddridge, B.G., R.R. Dickerson, R.G. Wardell, K.L. Civerolo, and L.J. Nunnermacker, Trace gas concentrations and meteorology in rural Virginia, 2, Reactive nitrogen compounds, J. Geophys. Res., 97, 20631-20646, 1992.

Dommen, J., A. Neftel, A. Sigg, and D.J. Jacob, Ozone and hydrogen peroxide during summer smog episodes over the Swiss Plateau: Measurements and model simulations, J. Geophys. Res., in press, 1995.

Draxler, R.D., Hybrid single-particle Lagrangian integrated trajectories (HY-SPLIT): Version 3.0, User's guide and model description, NOAA Tech. Memo. ERL ARL-195, Air Resour. Lab., Nat. Oceanic and Atmos. Admin., Silver Spring, Maryland, 1992.

Environmental Protection Agency (EPA), The 1985 NAPAP emission inventory (version 2): Development of the annual data and modeler's tapes, EPA Rep. EPA-600/7-89-012a, Research Triangle Park, N.C., 1989.

Goldstein, A.H., Non-methane hydrocarbons above a midlatitude forest: biogenic emissions and seasonal concentration variations, Ph.D. thesis, Harvard Univ., Cambridge, Mass., 1994.

Heikes, B.G., Formaldehyde and hydroperoxides at Mauna Loa Observatory, J.Geophys. Res., 97, 18,001-18,013, 1992.

Hilsenrath, E., D.F. Heath, and B.M. Schlesinger, Seasonal and interannual variations in total ozone revealed by Niimbus 4 backscattered ultraviolet experiment, I. Geophys. Res., 84, 6969-6979, 1979.

Holzworth, G.C., Mixing depths, wind speeds and air pollution potentials for selected locations in the United States, J. Appl. Meteorol., 6, 1039-1044, 1967.

Jacob, D.J., E.W. Gottlieb, and Michael J. Prather, Chemistry of a polluted cloudy boundary layer, J. Geophys. Res., 94, 12,97513,002, 1989a.

Jacob, D. J., S. Sillman, J. A. Logan, and S. C. Wofsy, Leastindependent-variables method for simulations of tropospheric ozone, J. Geophys. Res., 94, 8497-8509, 1989 b.

Jacob, D.J., J.A. Logan, G.M. Gardner, R.M. Yevich, C.M. Spivakovsky, S.C. Wofsy, S. Sillman, and M.J. Prather, Factors regulating ozone over the United States and its export to the global atmosphere, J. Geophys. Res., 98, 14,817-14,826, 1993.

Jobson, B.T., Z. Wu, H. Niki, and L.A. Barrie, Seasonal trends of isoprene, $\mathrm{C}_{2}-\mathrm{C}_{5}$ alkanes, and acetylenc at a remote borcal site in Canada, J. Geophys. Res., 99, 1589-1599, 1994.

Keene, W.C., B.W. Mosher, D.J. Jacob, J.W. Munger, R.W. Talbot, R.S. Artz, J.M. Maben, B.C. Daube, and J.N. Galloway, Carboxylic acids in clouds at a high elevation forested site in central Virginia, J. Geophys. Res., this issue.

Kleinman, L.I., Seasonal dependence of boundary layer peroxide concentrations: The low and high $\mathrm{NO}_{\mathrm{x}}$ regimes, J. Geophys. Res., 96, 20,721-20,733, 1991.
Kleinman, L., et al., Ozone formation at a rural site in the southeastern United States, J. Geophys. Res., 99, 3469-3482, 1994.

Lin, X., M. Trainer, and S.C. Liu, On the nonlinearity of tropospheric ozone production, J. Geophys. Res., 93, 15,879-15,888, 1988.

Logan, J.A., The ozone problem in rural areas of the United States, in Proceedings of the NATO Advanced Research Workshop on Regional and Global Ozone and Its Environmental Consequences, NATO ASI Ser. C; vol. 227, edited by I.S.A. Isaksen, pp. 327-344, D. Reidel, Norwell, Mass., 1988.

Logan, J. A., Ozone in rural areas of the United States, J. Geophys. Res., 94, 8511-8532, 1989.

Logan, J.A., M.J. Prather, S.C. Wofsy, and M.B. McElroy, Tropospheric chemistry: A global perspective, J. Geophys. Res., 86, 7210-7254, 1981.

Madronich, S., Intercomparison of $\mathrm{NO}_{2}$ photodissociation and U.V. radiometer measurements, Atmos. Environ., 21, 569578, 1987.

McKeen, S.A., E.-Y. Hsie, and S.C. Liu, A study of the dependence of rural ozone on ozone precursors in the Eastern United States, J. Geophys. Res., 96, 15,377-15,394, 1991a.

McKcen, S.A., E.-Y. Hsie, M. Trainer, R. Tallamraju, and S.C. Liu, A regional model study of the ozone budget in the eastern United States, J. Geophys. Res., 96, 10,809-10,845, 1991 b.

Monson, R.K., P.C. Harley, M.E. Litvak, M. Wildermuth, A.B. Guenther, P.R. Zimmerman, and R. Fall, Environmental and developmental controls over the seasonal pattern of isoprene emission from aspen leaves, Oecologia, 99,260-99,270, 1994.

Moy, L. A., R. R. Dickerson, and W. F. Ryan, How meteorological conditions affect tropospheric trace gas concentrations in rural Virginia, Atmos. Environ., 28, 2789-2800, 1994.

Munger, J. W., D. J. Jacob, B. C. Daube, L. W. Horowitz, W. C. Keene, and B. G. Heikes, Formaldehyde, glyoxal, and methylglyoxal in air and cloudwater at a rural mountain site in central Virginia, J. Geophys. Res., this issue.

National Research Council (NRC), Rethinking the Ozone Problem in Urban and Regional Air Pollution, National Academy Press, Washington, D.C., 1991.

Olszyna, K.J., J.F. Meagher, and E.M. Bailey, Gas-phase, cloud and rain-water measurements of hydrogen peroxide at a highelevation site, Atmos. Environ., 22, 1699-1706, 1988.

Olszyna, K.J., E.M. Bailey, and J.F. Meagher, $\mathrm{O}_{3}$ and $\mathrm{NO}_{\mathrm{y}}$ relationships at a rural site in Tennessee, Eos Trans. AGU, 74, (66), 1993.

Parrish, D.D., et al., The total reactive oxidized nitrogen levels and the partitioning between the individual species at six rural sites in eastern North America, J. Geophys. Res., 98, 2927-2939, 1993.

Paulson, S.E., and J.H. Seinfeld, Development and evaluation of a photooxidation mechanism for isoprene, J. Geophys. Res., 97, 20,703-20,715, 1992.

Poulida, O., R.R. Dickerson, B.G. Doddridge, J.Z. Holland, R.G. Wardell, and J.G. Watkins, Trace gas concentrations and meteorology in rural Virginia, 1, Ozone and carbon monoxide, J. Geophys. Res., 96, 22,461-22,475, 1991.

Sillman, S., The usc of $\mathrm{NO}_{\mathrm{y}}, \mathrm{HCHO}, \mathrm{H}_{2} \mathrm{O}_{2}$ and $\mathrm{HNO}_{3}$ as indicators for ozone- $\mathrm{NO}_{\mathrm{x}}$-hydrocarbon sensitivity in urban locations, J. Geophys. Res., in press, 1995.

Sillman, S., J. A. Logan, and S. C. Wofsy, The sensitivity of ozone to nitrogen oxides and hydrocarbons in regional ozone episodes, J. Geophys. Res., 95, 1837-1852, 1990a. 
Sillman, S., J. A. Logan, and S. C. Wofsy, A regional-scale model for photochemical production of ozone in the United States with subgrid representation of urban and power plant plumes, J. Geophys. Res., 95, 5731-5748, 1990 b.

Talbot, R.W., B.W. Mosher, B.G. Heikes, D.J. Jacob, J.W. Munger, B.C. Daube, W.C. Keene, J.M. Maben, and R.S. Artz, Carboxylic acids in the rural continental atmosphere over the eastern United States during SCAPE, J. Geophys. Res., this issue.

Trainer, M., E.J. Williams, D.D. Parrish, M.P. Buhr, E.J. Allwine, H.H. Westberg, F.C. Fehsenfeld, and S.C. Liu, Models and observations of the impact of natural hydrocarbons on rural ozone, Nature, 329, 705-707, 1987.

Trainer, M., et al., Observations and modeling of the rcactive nitrogen photochemistry at a rural site, J. Geophys. Res., 96, 3045-3063, 1991.

Trainer, M., et al., Correlation of ozone with $\mathrm{NO}_{\mathrm{y}}$ in photochemically aged air, J. Geophys. Res., 98, 2917-2925, 1993.
R. S. Artz, Air Resources Lab, NOAA, Silver Spring, MD 20910.

R. Dickerson, Department of Meteorology, University of Maryland, College Park, MD 20;742.

B. G. Heikes, Graduate School of Oceanography, University of Rhode Island, Narragansett, RI 02882.

L. W. Horowitz, D. J. Jacob (corresponding author (email: djj@io.harvard.edu)), and J. W. Munger, Division of Applied Sciences and Department of Earth and Planetary Sciences, Harvard University, Cambridge, MA 02138.

W. C. Keene, Department of Environmental Sciences, University of Virginia, Charlottesville, VA 22903.

(Received January 1, 1994; revised October 25, 1994; accepted November 22, 1994.) 